\title{
The application of reader-response theory to teach symbolism in literature class for efl students
}

\section{Putri Rindu Kinasih}

Universitas Bunda Mulia, Indonesia

pkinasih@bundamulia.ac.id

*) correspondence: pkinasih@bundamulia.ac.id

\begin{abstract}
For years, scholars believed one effective approach that can be used in teaching literature in EFL context is reader-response approach yet very limited study can be found about the application of reader-response theory in teaching symbolism. Whereas, symbolism is considered as the most important elements of serious imaginative literature which provide rich sources of insight. The problem is, deciding exactly what is represented by a symbol is not an easy thing to do, though the general meaning is clear because a symbol most commonly represents something unnamed. This research aimed to find out the application of reader-response theory in teaching symbolism. This research observed 16 participants majoring in English Literature program. Within four weeks, the participants were asked to read selected poems and short stories and asked to write a reflective writing as a response. Then, the writings were assessed by using critical thinking rubric. From this research, it can be drawn that the participants' score of symbolism interpretation were increasing by the end of the research. In other word, reader-response theory is beneficial to the improvement of students' inadequacies in studying symbolism and offers potential benefits to solve problems in literature discussion such as low self-confidence and fear of stating out different interpretations. By the end of the research, the participants are more accustomed to express various ideas and more motivated to explore more supporting sentences to strengthen their ideas.
\end{abstract}

Keyword: reader-response; symbolism; literature; reflective writing

\section{INTRODUCTION}

Without doubt, literature plays important roles in life. Mays (2017) believed that instead of just talking about things, literary works bring life to the reader by representing experiences directly; in which they engage the readers' emotions, imaginations and senses and intellects (p. 3). Literature also explores issues and questions relevant in life by experiencing the difficult situations and human's complexity from various points of view (p. 7-8). In short, as Haraway (as cited in Bruns, 2011) stated that literature portrays the human's approaches to knowledge discovery with the advantage or being nowhere while claiming to see comprehensively. This stage of recognizing something in ourselves in a literary work is important for self-knowledge, comfort and consolation (Bruns, 2011, p. 18). In addition, literature also awakens people to the richness of language. The more people read literature, the more they see how the authors use language in diverse ways in order to describe numerous self-expressions such as joy, pain, laughter, or rage (Mays, 2017, p. 8). However, despite its importance, teaching literature, especially in EFL context still becomes a challenging thing to do.

From the teacher's side, there is an issue in which the teachers usually have a strong authority to push the students having the same understanding of literary work as what the authors intended to mean (Basthomi, 2001; Brooks and Warren as cited in Shen, 2001). Consequently, students do not have any space to explore the possible multi meaning of the literary works. Furthermore, Miall (as cited in Basthomi, 2003) added that sometimes the teacher only asks students to memorize a great number of literary terms. Consequently, the role of students in the classroom is neglected whereas Miall strongly stated that students should become readers in order to be able generating their own 
meanings or significance of literary works. With this in mind, in order to gain more significant literature study in class, teaching literature must be shifted from transmission to transaction paradigm (Herlina, 2016).

Scholars believed one effective approach that can be used in teaching literature is reader-response approach; hence study about reader-response and literature has been done extensively (Febriani, 2019; Iskhak, Saleh, Sofwan, Hartono, 2017; Trisnawati, 2009). Firstly, in her study, Febriani (2019) stated that by applying reader-response approach in a literature class, the students are able to express not merely their personal feelings (like, dislike, sad, unhappy feelings, and so on), but they had also showed that they had a good start to think critically upon literary works. Febriani argued that reader-response prompts were helpful in giving aids to the students that they give the students idea how to write down their ideas and thoughts in minds, even though the student's writing are still dominated by expressing feelings. She added that, this issue might be resulted by the possibility of knowledge lacking and practice critical thinking.

In line with the study above, Iskhak, Saleh, Sofwan, Hartono (2017) also investigated the effects of reader-response journals on the quality of teacher trainees' responses to literary works. The study followed Rosenblatt's reader response theory, literacy principles, and sociocultural views, which resulted in three findings. First, the study showed that RRJ gave effects to the pre-service EFL trainees' quality in writing reader responses to literary works, short stories, assigned. Quantitatively, the subjects' critical thinking improved as the statistic evidences indicated differences between before and after the treatment. Second, the study showed participants' active participation in RRJ projects in literature class indicated their deep engagements in the stories. Their enjoyment in aesthetic reading-writing events was also reflected by their active involvement. Lastly, the study revealed that there is an improvement of the participants' critical reflections. Before treatments, the participants tended to use their limited rooms and lack their own authorship driven by their own original thoughts and affective experiences. Yet, after the treatment, the participants are able to express their feelings and critical comments while and after enjoying the stories.

Lastly, Trisnawati (2009) also analyzed the implementation of reader-response theory on the reading of Booker T. Washington's autobiography Up from Slavery. The students were given the work to read without telling them what it was about, as a part of consequences to employ the readerresponse theory. Hence, the readers were free to assume the context and the theme of the work. The study showed that by implementing reader-response theory, the students' are able to enjoy the literary works, as they wrote 'it is nice story'. Then, the students are able to grasp the value of life as they mentioned that life struggle in Up from Slavery can be seen as a universal value that the students can agree with. Lastly, Trisnawati added that the application of reader-response theory also evokes the students' interaction and collaborative cooperation in a way they give the responses such as expressing disagreement, opinion, even confusion towards the literary works. All in all, the students have written their interpretation and meaning from Up from Slavery.

On the whole, a considerable amount of research had successfully spotlighted the positive result of the implementation of reader-response approach. However, none of the study above showed how reader-response approach is used in order to develop students' understanding of symbolism in literature. Febriani (2019) analyzed how reader-response approach in understanding the students' ability to connect their experiences, feelings and thought towards selected literary works; 'The Story of an Hour' by Kate Chopin, 'Misery' by Anton Chekhov and 'Lord of the Flies' by William Golding. Iskhak et al. studied the improvement of the participants' critical thinking by assessing their reading test. While, Trisnawati (2009) analyzed the students' ability to enjoy the reading passage, and the ability to grasp the life value. Whereas, symbolism is considered as the most important elements of serious imaginative literature which provide rich sources of insight (McMahan, Funk, Day \& Coleman, 2017, p. 124). However, it is important to be underlined that symbols in literature rarely have a single, unambiguous meaning (p. 126). In addition, in prose and poetry a symbol most commonly represents something unnamed, therefore it may be difficult to decide exactly what is represented by a symbol, though the general meaning is clear (Hargreaves and Robins, 1981, p. 22; Mays, 2017; p. 335). 
Considering this, the interpretive skill is extremely necessary to detect and understand them because the meaning of literary work is often reinforced through symbolism (McMahan, Funk, Day \& Coleman, 2017, p. 124). Therefore, this research is aimed at answering the following question:

1. To what extent the use of reader-response approach manifested in the students' literary analysis of symbolism?

\section{Extensive reading}

Aside from aiming students to develop good reading habits, to build up knowledge of vocabulary and structure; extensive reading approach also aims to get students reading in the second language and liking it (Day and Bamford, 1998, p. 6). The New York City Board of Education mentioned that extensive reading also can be understand as "supplementary" reading with a certain goal, that is the development to the point of enjoyment of the ability to read the foreign language $(1931, p .301)$. Devine (1984) also added that students with higher reading ability take reading as a meaning centered approach. Day and Bamford (1998) believed that the previous view of reading is the kind of perspective that fostered by extensive reading (p. 7). During the implementation of extensive reading, students are encourage to read as much as possible. In addition, students should explore a variety of materials for a different reasons and in different ways. Students select what they want to read while the teacher orients students to the goal of the program. The teacher also should keep track of what each student reads and guide students in getting the most out of the program (Day and Bamford, 1998, p. 7-8).

\section{Reader-response approach}

Reader-response theory is rooted from transactional theory suggested by Rosenblatt (1988). She explained that reading and writing share a necessary involvement with text. The term transaction is used to explain the relationship between each elements conditions and is conditioned by other in a mutually constituted situation. In other words, the term reading transaction means that reading act is a transaction involving a particular reader and a particular text in a particular context. In addition, the reader-response approach offers integrated reading-writing activities. Bressler (1994) explained that the difference between Rosenblatt's reader-response and all other critical approach is that it switches the emphasis from the text as the exclusive determiner of meaning to the important role of students as an essential participant in the reading process and meaning creation (p. 49). In result, a reader of literary work becomes an active participant which produces interpretation of the literary work. Spiegel (1998) suggested that in most response-based approach, reading is mostly done through sustained silent reading. Thus, responding is a follow-up activity done through writing of the readers have gained. Practically, the expected reader response approach normally covers strategies such as engaging, describing, explaining, interpreting, connecting and judging which evokes the critical reflections from the reader (Beach and Marshall, 1991).

Langer (1994) stated that for literature pedagogical purposes, there are basic distinctions in the ways readers and the original author orient themselves towards making sense when engaging in the activity for literary or discursive purposes. In should be noticed that in both cases, the readers have the sense of the local meaning they are reading, writing, or thinking about; that is why it is suggested for teachers to apply reader-response approach in teaching literature in class (p. 2). The goal of applying reader-response approach in class is creating the thought-provoking literature class, in which the students are encouraged to negotiate their own meanings by exploring possibilities. Below, Langer wrote the guidelines of conducting a reader-response based class for teaching literature:

1. Teacher must use the class session as a time for students to explore possibilities, rather than just recounting the acquired meanings.

2. In conducting a writing or discussion session, the teacher must always begin with their initial impressions. This actionR will validate their attempt to understand, build, and refine meaning. 
3. Then, as the teacher gives instructions, it should be noted that the instructions must move beyond the prior impressions, involve scaffolding the students' ideas. In this stage, the teachers' must act as a listener, not an information giver.

4. Next, the teacher must encourage wonderings and hunches more than absolute clue. Whenever possible, the teacher should ask questions that tap students' knowledge. Pick up on what they say rather than following your own agenda or the sequence of the piece you are reading.

5. The teacher must realize that there is more than one way to interpret any piece of literature. Hence, it should be noted that the teacher should leave the room for future possible interpretations.

In conclusion, the teacher should conduct the lesson by performing three major sections: inviting initial understandings, developing interpretations, and taking a critical stance. These replaced traditional lesson segments such as vocabulary review or plot summary, providing overall structural options to include or overlook (knowingly) in any given lesson (1994, p. 6-7).

Robson (2020) stated that the definition of literature has been question for years as it has a long history and in fact it is historically bounded (p. 1). Turning to the Oxford English Dictionary (OED), Robson mentioned that the clearest meaning definition of literature is 'writing which claim to consideration on the ground of beauty of form or emotional effect'. He added that previous definition contains two crucial elements for understanding; which are beauty and emotional effect. However the two elements mentioned also evokes another question, as there is no exact strategy to define beauty. Similarly, emotional effect is broad enough to cover everything from being profoundly moved to faintly irritated (p. 2). Thus, Robson (2020) stated that the question 'what is literature' remains an open question, since any answer to the question always turn out to have seized on something (p. 8).

Despite its complicated definition, literature plays significant roles in human life. Mays (2017) stated that instead of just talking about things, literature works bring life to the reader by representing experiences directly; in which they engage the readers' emotions, imaginations and senses and intellects (p. 3). Literature also explores issues and questions relevant in life by experiencing the difficult situations and human's complexity from various points of view. In other words, literature invites us sometimes to question conventional thinking and sometimes to see its wisdom, even as it helps us imagine altogether new possibilities. (p. 7-8). In short, as Haraway (as cited in Bruns, 2011) stated that literature portrays the human's approaches to knowledge discovery with the advantage or being nowhere while claiming to see comprehensively. This stage of recognizing something in ourselves in a literary work is important for self-knowledge, comfort and consolation (Bruns, 2011, p. 18). In addition, literature also awakens people to the richness of language. The more people read literature, the more they see how the authors use language in diverse ways in order to describe numerous selfexpressions such as joy, pain, laughter, or rage. The study of literature enhances our command of language and our sensitivity to its effects and meanings in every form or medium, providing interpretation and communication skills especially crucial in our information age (Mays, 2017, p. 8).

\section{Symbolism}

Broadly speaking, Hargreaves and Robins (1981) stated that symbol is anything which stands for something else. In its relation with imagery, McMahan, Funk, Day \& Coleman (2017) stated that if a repeated image gathers significant meaning and seems to stand for something more than itself, it then becomes a symbol (p. 125). For example, a letter of the alphabet is a symbol for a sound. However, they added that usually the word is reserved for an object or idea or even a word that represents abstraction which cannot for one reason or another be dealt with literary (Hargreaves and Robins, 1981, p. 22). The thing that is symbolized is called the referrent. Furthermore, Hargreaves and Robins (1981) added that a symbol also can be understood as a kind of metaphor in that it associates two things that share qualities and attributes. In prose and poetry a symbol most commonly represents something unnamed, therefore it may be difficult to decide exactly what is represented by a symbol, though the general meaning is clear. Some objects are used so often and consistently as symbol that 
their meaning is clear to most people, and they become public symbols. For example in European literature, the rose is very common symbol for loveliness and transience. Also, water has become an agent of cleansing and renewal and has become a public symbol used all over the world (p. 22).

Furthermore, less commonly private symbols are used more obvious in poetry rather in prose. For example, Yeats used the ancient city of Byzantium to symbolize his ideal alternative he lived in, while Kofi Awoonor uses the weaver-bird to symbolize European colonialist (Hargreaves and Robins, 1981, p. 23). What is more, Hargreaves and Robins emphasized that there are great difference between symbolism and metaphor despite their likeness. Symbolism is the extended of metaphor; meaning that it runs throughout the whole piece of writing. The strength of symbolism lies in the author's ability to deal with a subject without actually mentioning it (1981, p. 23). Lastly, McMahan, Funk, Day \& Coleman (2017) stated that there is a strategy to recognize an image, a character, or an action carries symbolic meaning, which is by paying attention to the context suggests the significance.

\section{Reflective writing}

According to Moon (2006) reflection is a form of mental processing - like a form of thinking that people may use to fulfill a purpose of to achieve some anticipated outcome. However, she strongly emphasized that we do not reflect on 'simple' things like the route to the corner shop, but on 'things in which there is no obvious solution'. Reflection is applied to relatively complicated ideas which are based on further processing of knowledge each individual has possessed (p. 36-37). Moon added that the outcome of reflection is most likely in the form of reflective writing, in which usually seen and assessed by a tutor. In addition, reflective writing in the academic context is also likely involve conscious and stated purpose for the reflection, with a specified outcome of learning, action or clarification. Hatton and Smith (1995) describe the level of reflective learning as follows:

1. Descriptive writing is a writing that is not considered to show evidence of reflection. It is just a description with no discussion beyond discussion.

2. Descriptive reflection is a form of writing with a description of an event. Mostly the reflection is from one perspective.

3. Dialogic reflection is form of perspective which shows a 'stepping back' from events and actions which lead to a different level of contemplation about discourse with self and exploring the discourse of events and actions. The reflection is analytical or integrative, even though may reveal discrepancy.

TABLE 1: Baron's rubric with different performance levels (2015, p. 133)

\begin{tabular}{|c|c|c|c|c|c|}
\hline Area Assessed & O Points & 1 Point & 2 Points & 3 Points & $\begin{array}{c}\text { Student } \\
\text { Total }\end{array}$ \\
\hline $\begin{array}{l}\text { Controlling Idea } \\
\text { (Thesis Statement) }\end{array}$ & $\begin{array}{l}\text { One or more of the } \\
\text { thesis statement } \\
\text { elements is weak or } \\
\text { missing. The focus } \\
\text { of the work is not } \\
\text { presented. }\end{array}$ & $\begin{array}{l}\text { One of the elements } \\
\text { of the thesis statement } \\
\text { is weak and does not } \\
\text { accurately present the } \\
\text { scope of the work. }\end{array}$ & $\begin{array}{l}\text { Thesis statement } \\
\text { includes a subject } \\
\text { and focus, provides } \\
\text { a strong foundation } \\
\text { for the knowledge } \\
\text { presented. }\end{array}$ & $\begin{array}{l}\text { Thesis is clearly } \\
\text { delineated including } \\
\text { a subject and focus, } \\
\text { and presents a strong } \\
\text { direction for the work. }\end{array}$ & \\
\hline $\begin{array}{l}\text { Conclusions } \\
\text { Reached }\end{array}$ & $\begin{array}{l}\text { A conclusion is } \\
\text { not made from the } \\
\text { evidence offered. }\end{array}$ & $\begin{array}{l}\text { Some detailed } \\
\text { conclusions are } \\
\text { reached from the } \\
\text { evidence offered. }\end{array}$ & $\begin{array}{l}\text { Several detailed } \\
\text { conclusions are } \\
\text { reached from the } \\
\text { evidence offered. }\end{array}$ & $\begin{array}{l}\text { Numerous detailed } \\
\text { conclusions are } \\
\text { reached from the } \\
\text { evidence offered. }\end{array}$ & \\
\hline $\begin{array}{l}\text { Information } \\
\text { Gathering }\end{array}$ & $\begin{array}{l}\text { Information is } \\
\text { gathered from course } \\
\text { materials only, which } \\
\text { are used sparingly if } \\
\text { at all. }\end{array}$ & $\begin{array}{l}\text { Information is } \\
\text { gathered from limited } \\
\text { course materials, with } \\
\text { some outside sources. }\end{array}$ & $\begin{array}{l}\text { Information is } \\
\text { gathered from } \\
\text { multiple appropriate } \\
\text { sources. }\end{array}$ & $\begin{array}{l}\text { Information is } \\
\text { gathered from multiple } \\
\text { appropriate sources } \\
\text { and properly cited. }\end{array}$ & \\
\hline $\begin{array}{l}\text { Outline, Mechanics, } \\
\text { Usage, Grammar, } \\
\text { Spelling [MUGS] }\end{array}$ & $\begin{array}{l}\text { Weakly organized and } \\
4 \text { or more errors in } \\
\text { MUGS. }\end{array}$ & $\begin{array}{l}\text { Well organized, but } \\
\text { demonstrates illogical } \\
\text { sequencing, or } \\
\text { structure errors or } 2 \text { to } \\
3 \text { errors in MUGS. }\end{array}$ & $\begin{array}{l}\text { Well organized, but } \\
\text { demonstrates illogical } \\
\text { sequencing, or } \\
\text { structure errors, and } \\
1 \text { error in MUGS. }\end{array}$ & $\begin{array}{l}\text { Well organized, } \\
\text { demonstrates logical } \\
\text { sequencing and } \\
\text { structure with no } \\
\text { errors in MUGS. }\end{array}$ & \\
\hline
\end{tabular}


Kinasih, P., R.

Hatton and Smith added that for assessment purposes, the students usually were asked to produce reflective account. In initial account, the students' output might be disappointing because the outputs are superficial. Thus, they explained that the assessor should take care and not reject all descriptive writing. In early stage, some description is necessary in a reflective account that is used in a formal situation to provide the background of reflection. However, the assessor must understand fully the different role of the two types of writing and should not be confused.

\section{Critical thinking}

Lau (2011) defined critical thinking as thinking clearly and rationally. Critical thinking involves thinking precisely and systematically, and the most important thing is, it follows the rules of logic and scientific reasoning, among other things (p. 1). Because of its importance, scholars have study the way to create a way to assess critical thinking skills. Barron (2015) stated that one of the strategies to measure critical thinking skill is by conducting written assignment (p. 132). The table below presents an example for assessing a participant's critical thinking skill based on their writings:

From the table above, it can be seen that the writing is assessed from four areas; controlling idea, conclusion reached, information gathering, and the outline (mechanics, usage, grammar, spelling).

\section{METHODS}

This research will be conducted by using qualitative research method in which, Given (2008) believed that this method is designed to explore the human elements of given topics, where specific methods are used to examine how individuals see and experience the world. Given added that quantitative research methods are best for addressing many of why questions that researchers have in mind. In addition, his method is typically used to explore new phenomena and to capture individuals' thoughts, feeling, or interpretations of meaning and process (p. xxix).

The present research will be focus on the application of reader-response approach in the participants' understanding and interpretation of symbolism. Therefore, document analysis is used as the qualitative research design, by using the participants' reflective essays as the instrument to seek for how the participants manifest their thoughts using reader-response literary analysis in the form of their reflective writing. Portfolio records the participants' response of the selected literary works. The portfolio consisted of the participants' reader response of two short stories and two poem. The object of study are selections of series of prominent literary works or known as canon, such as The Lottery by Shirley Jackson, A Hunger Artist by Franz Kafka, The Road Not Taken by Robert Frost, and The Sick Rose by William Blake. Lastly, the participants' writing will be analyzed by using the rubric from Barron (2015).

\section{Research Procedure}

The participants of this study are the second semester students, majoring in English Language and Literature (BBI) of UBM. Thus, the participants are familiar of the literary works, and various terms of literature as well. The class consists of 16 participants, 11 females and 5 males.

The research will be started by understanding the procedure of using reader-response approach from Rosenblatt's theory (1988). Then, the writer selects the research instrument; in which are taken from the selections of 'The Norton Introduction to Literature' (2017) and 'Literature and the Writing Process' (2017). The object of study are selections of series of prominent literary works or known as canon, such as The Lottery by Shirley Jackson, A Hunger Artist by Franz Kafka, The Road Not Taken by Robert Frost, and The Sick Rose by William Blake.

The class flow chart is displayed in the picture below: 
The writer assigned the participants to read the selected literary works one week before the class started. Thus, the students will have time to do extensive reading and enjoy the reading.

During the reading week, the writer controled the reading progress through group class chat group and asked whether they found any difficult vocabularies and checked the editions of the students' literary work.

In the upcoming meeting, the writer conducted the discussion in the class about the work the participants have read in prior. The discussion was limited into these question:

- How is the participants' feeling after reading the passage?

- Do the participants have any prior/ similar experiences related with the work they have read?

- How is the literary work affects them, their perspective/ thoughts after they read it? Does it evoke something in their mind?

The writer should avoid directing students toward one solid opinion and should not talk about the meaning of the symbol.

After the discussion session ends, the students were asked to write down their interpretation about the symbol in the literary works. The participants were encouraged to consider the pervious discussion during the process of reflective writing.

Once the writings were collected, the writer gave follow-up questions about the writing process about their dificulties and their feeling. At the end of the class, the writer gave an introduction and explained the background about the next literary work extensive reading assigment. The students read the literary work as a homework.

Picture 2: Class activity flowchart 
Kinasih, P., R.

From the chart above, it can be seen that during the discussion session, the writer is not elaborating the symbols from the literary work, but more like eliciting the participants' prior experiences and their feeling - whether or not they enjoy the indulgence of reading. There are two reasons of doing the strategy above. First, the writer is trying to encourage and ensure participants to express their own opinion and perspective. Secondly, by not discussing the symbols during the discussion session also means that the participants are encouraged to write down their own original interpretation and not copying their friends' opinion after they overheard their friends' answers.

\section{Results and Discussions}

First week - The Sick Rose

In the first week, the writer assigned the participants to read and analyze a poem, The Sick Rose by William Blake. The chart below is the result of the participants' reflective by using Baron's rubric of critical thinking assessment:

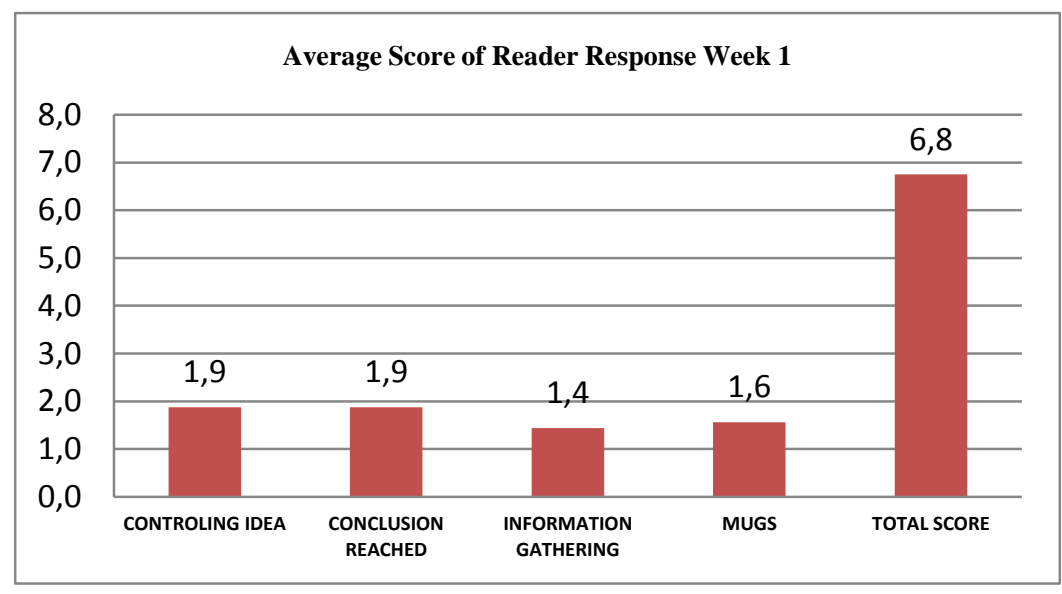

From the chart above, it can be seen that in general the participants were still facing some difficulties in interpreting the symbol of rose and worm in William Blake's The Sick Rose. The average score of the controlling idea is 1.9 out of 3 , and the conclusion average score is also 1.9 out of 3 . The lowest score from the chart is the information gathering section with 1.4 and the second lowest score is the MUGS (mechanics, usage, grammar and spelling) with 1.6 out of 3.

From the data above, it can be seen that in general the participants were still not accustomed to state a clear thesis statements regarding with extended meaning of rose and worm in the poem. From the participants' writing, there are 38 interpretations came up from the word rose in the poem - in which $18 \%$ of the collected interpretations shows that rose is mostly associated with human being. And the second highest result with $16 \%$ is the association of rose with love. Mays (2017) stated that in general people would associate the rose with love and beauty (p. 853). Therefore, the participants' interpretation is quite general.

However, Mays stated that it is not comprehensive if the participants are only asked the standard question - what is rose? (p. 854). Mays added that William Blake's poem actually cries out against the misuse of the rose, against its desecration, implying that instead of a healthy joy, there has been in this case destruction and hurts (p. 853). Interestingly, the participants were able to draw similar analysis as Mays' with 36 interpretations of worm. From the participants' writing, 16\% of the result showed an association of worm with destruction. Thus, despite the small percentage and small score result of controlling idea, the participants were able to elicit the meaning of rose and worm symbolism.

Furthermore, from chart 1, it can be seen that the lowest score is shown in information gathering with only 1.4 out of 3 . From the discussion in the class, only 2 participants admitted having related experiences as shown from the poem. They shared that they have encountered the same kind of sadness, betrayal and destruction just like what happened to the rose in the poem. While, the rest of the participants shared they never experienced similar kind of grief and loss. Consequently, while 
interpreting the symbols they just relied on what is displayed from the text. Here lies the reason of the low number of information gathering.

In addition, the low score on the MUGS section is generally resulted from the punctuation errors that the participants made. Interestingly, the participants are still making basic mistakes such as, capitalization and run off sentence. Thus, the participants' average total score is only 6.8; which is quite low compared to the perfect score -12 points.

\section{Second week - The Road Not Taken}

During the following week, the participants were asked to read and explore The Road Not Taken by Robert Frost. The writer also followed up the reading assignment, to check whether the participants finds various version, or any difficulties during the reading time. The chart below is the result of the participants' reflective writing about The Road Not Taken:

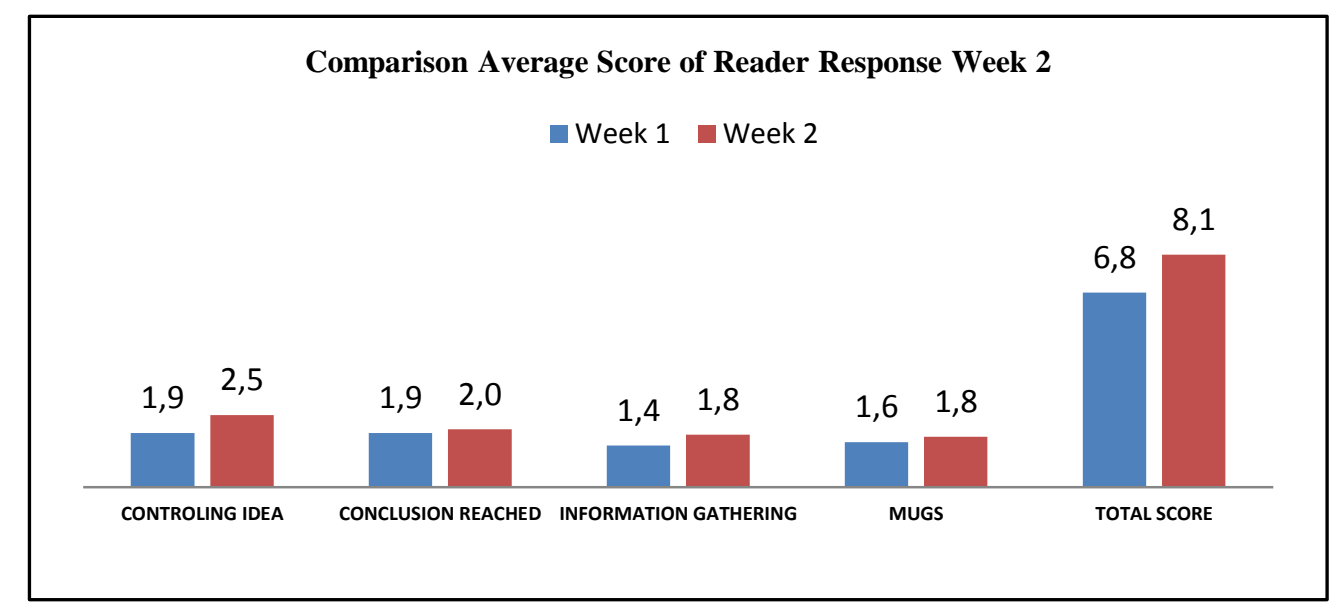

Chart 2: Average score of reader response week 1 and week 2

From the chart above, it can be seen that in general the participants' ability to write a reader response writing is increasing. Firstly, it can be seen that the highest progress is the participants' ability to write a clear thesis statement. On the second week, the participants' ability to write thesis statement is increasing to 2.5 out of 3. The participants' ability to draw a conclusion also increased to 2,0 out of 3. In addition, the information gathering section is also increased to 1.8 point out of 3 . Then, the results also showed the progress in MUGS (mechanics, usage, grammar and spelling) with 1.8 out of 3. The participants' error are still dominated by the same problem which are the lack of punctuation and run off sentences.

On the contrary with the first week, the participants' interpretations are more homogeneous on the second week. There are 16 answers gathered regarding the interpretation of road in the poem - in which $88 \%$ of the interpreted the roads as a life or important decision. Whilst the remaining answers showed that the road is seen as the representative of idealism versus realism in life. The participants' answers are aligned with what Robb (2014) had stated; that in Frost's poem, the two roads symbolize the choices we make during our lives as well (p. 90).

In addition, the follow-up discussion in class is also getting more alive compared to week 1 . This time, mostly the participants expressed that it is easier to understand the poem because they have encountered the same situation when they have to make important decisions such when they had to choose the major in the university. Considering this, the participants are able to reached similar conclusion in their writing - in which the subject in the poem is in the midst of confusion. The participants' conclusions are similar with what Orr had stated - that the person who stands in the woods is debating his path. He is literally betwixt and between (2015, p. 167). 
Kinasih, P., R.

In conclusion, the participants said that the poem is more relatable with them. This being said, the participants' score on every sections are increased on the second week. Here lies the reason why the participants' total score is increased to 8,1 point out of 12 .

\section{Third week - A Hunger Artist}

On the third week, the participants were asked to read Franz Kafka's A Hunger Artist. Then, in the class, a discussion was held to talk about their feelings, perception and how the story affects them. The chart below is the result of the participants' reflective writing about $A$ Hunger Artist:

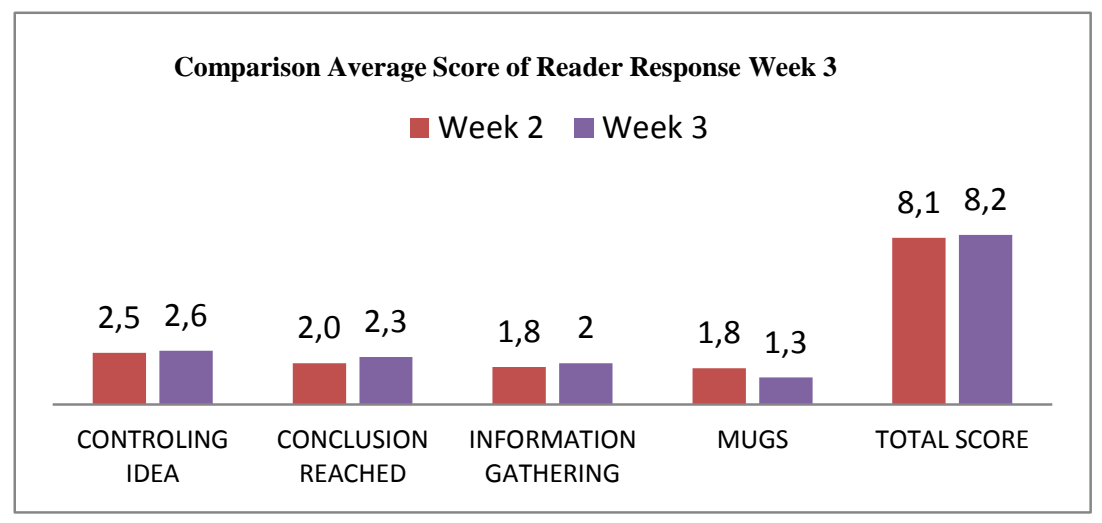

Chart3: Average score of reader response week 2 and week 3

From the chart above, it can be seen that the participants there are progress of participants' thinking skill even though it is not too significant. The controlling idea sections develops into 2,6, the conclusion section also arises into 2,3 and the total score arise by 0,1 point into 8,2 on the third week. However, the score for MUGS (mechanics, usage, grammar and spelling) section declines by 0.5 into 1.3 on the third week.

During the discussion on the third week, the participants shared that in general they felt sorry for the misfortune that happened to the artist. Interestingly, the feeling they felt towards the artist is interpreted into many kind of things when they are asked to interpret what the hunger artist symbolizes in the story. There are 20 answers came out from the participants' writings, in which $40 \%$ of them associated the artist as symbol of dissatisfied person. In other words, by the third week, $40 \%$ of the participants were able to grasp the essence of dissatisfaction in the story - as written by Gale (2016) that hunger is the prominent symbolic motif in A Hunger Artist, and characterized by the artist's lifelong feeling of dissatisfaction. The artist's inability to find the food he likes is symbolic of his inability to engage the joy of life. In addition, there are $25 \%$ answers which related the artist in the story with the artist in modern time - an artist is considered as a robot that relies only to the TV program rank. They shared that when the time comes, the public will get bored and eventually no matter how talented the artist is, he/she will be forgotten. Thus, the artist himself is a symbol of momentary fame. While, the remaining $35 \%$ of the participants interpret the story as a series of unfortunate events.

Furthermore, from the writings on Week 3, the participants were also able to interpret the character impresario in the story as an opportunist person. Not only have they elaborated the impresario's interest, but they also relate his behavior with the tragic issue in entertainment world today. The participants were able to argue that what the impresario does in the story actually represented what the entertainment industry does to the celebrity nowadays. In general they wrote that the impresario is leaving the artist because the artist is no longer beneficial for him. 


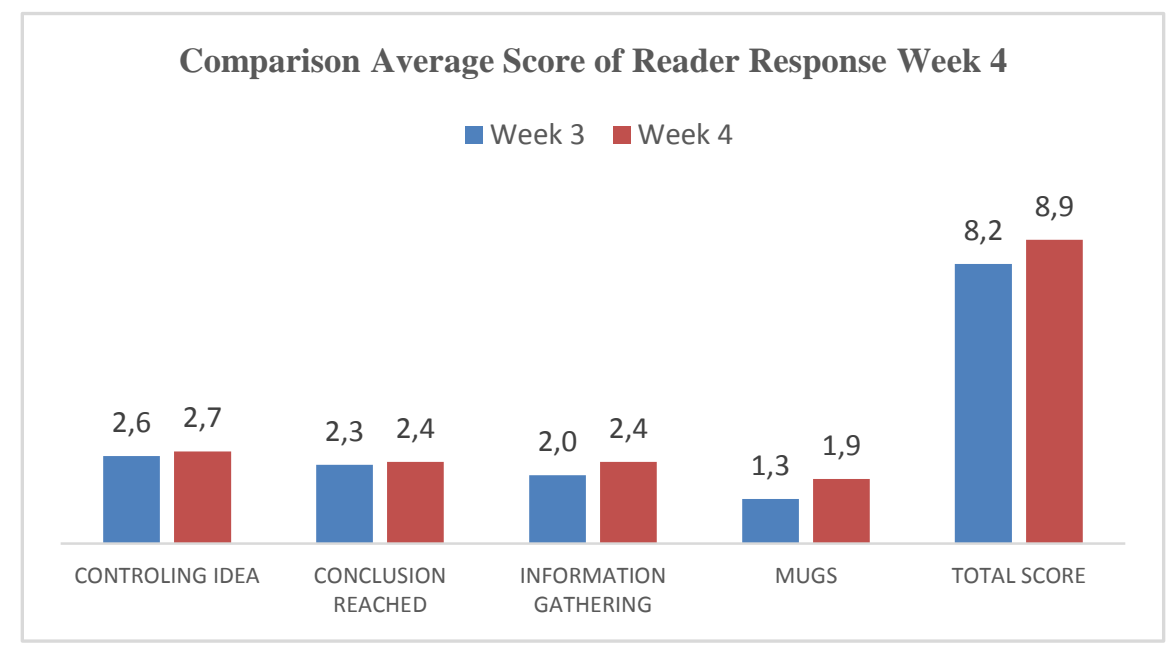

Chart 4: Average score of reader response week 3 and week 4

Interestingly, $25 \%$ of the participants were also able to highlight in their writings that in entertainment industry there is nothing permanent. When the public get bored, or if the artists get old, then the celebrities will not be invited in any TV program. While, the remaining $75 \%$ of the participants shared that the people in the story represents the reality - in general people cannot appreciate difficult art. They wrote that the reason why the artist was forgotten is because people in general did not get the interesting part of watching people fast. The result above shows that not only the participants are able to understand the underlying meaning in the story but they also can relate the theme and conflict in the story with the reality around them.

By this week, it is also important to take a look at the objective of a reader response class - that is not to adjust the participants' answers nor to make them all similar, yet to elicit broaden opinion and thoughts from the participants. Thus, despite the lowest score of the MUGS section by far, the participants managed to write broaden writing on week three.

\section{Fourth week - The Lottery}

On the fourth week, the participants are asked to read Shirley Jackson's The Lottery. Then, in the class, a discussion was held to talk about their feelings, their opinions and how the story affected them. The chart below is the result of the participants' reflective writing about The Lottery:

From the chart above, it can be seen that in general, the participants' critical thinking skills are developing in the fourth week. The participants' score in every section reached the highest mark this week. Thus, it can be said that the participants' ability to interpret the symbol in the fourth week is getting better compared to their ability in the previous weeks.

The plot twist in the story triggered the participants to speak out more to express their feelings. From the discussion in the class, mostly the participants said that they were surprised with the plot twist because they rarely find this shocking ending in their Indonesian short stories. The rest of them shared that the story is somewhat disturbing and make them sad. Also, they shared that the story reminded them to a cult movie they just watched recently, Midsomar. Thus, shared how similar the after effect of watching Midsomar and reading Jackson's The Lottery.

Whilst, from their writing, $63 \%$ of the participants were able to interpret the lottery as a symbol illogical tradition. They shared that the lottery in the story represents the cultural tradition which are done until the present days without knowing the objective or the function of the ritual itself. However, only two people of these $63 \%$ were able to gather detail information and mentioned the examples of illogical ritual. From their writing, they shared how the Dani people from West Papua participate in a very painful ritual where any person who related to a deceased is obligated to cut off their fingers. Also, they also wrote that the ritual is done to honor the dead as an expression of sorrow and sadness. 
Kinasih, P., R.

In addition, even though the rest of the participants did not relate the lottery with a cultural tradition, they wrote various deep interpretation. First, 19\% of the participants interpreted the lottery as ignorance in our society. People usually will just do things as insignificant habits. They will question their daily activities when they become the losing side, like Tessie in the story. Also, the participants were able to relate the lottery in the story with battle between minority and majority. The rest $19 \%$ of them wrote that the majority will always be the winner in the world no matter how stupid or how nonsense their acts are.

All in all, it can be seen that reader-response theory offers potential benefits to solve problems in literature discussion such as the fear of stating out different interpretations and the participants low participation. The chart below, show the participants' progress from Week 1 to Week 4:

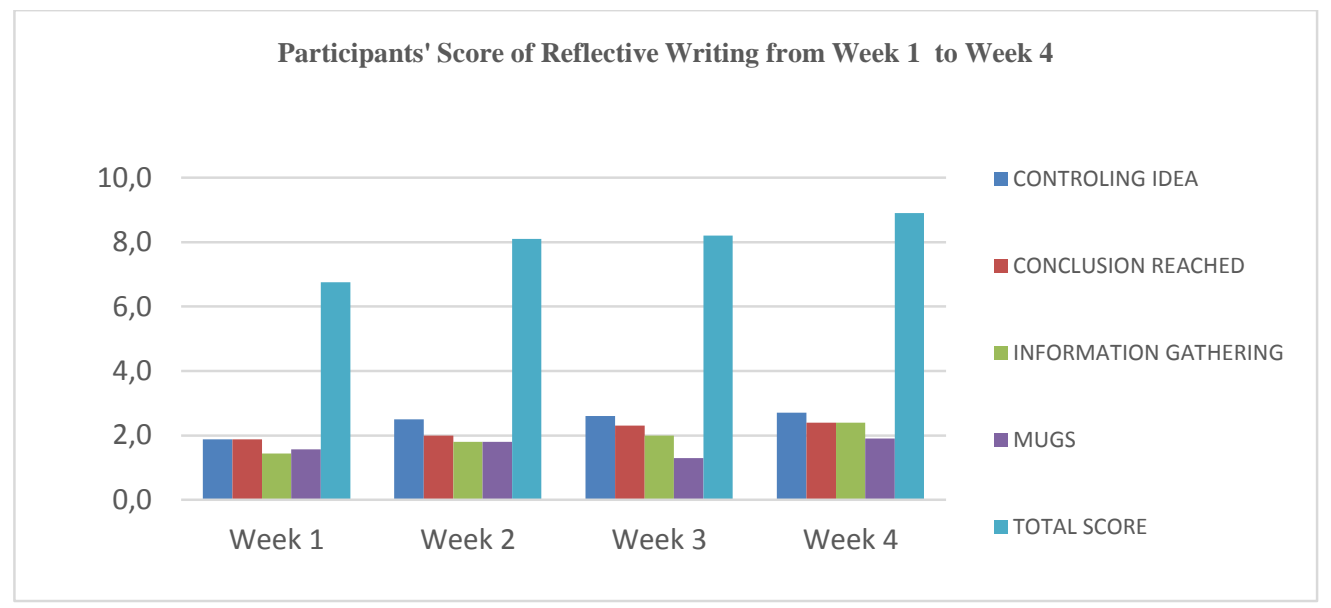

Chart 5: Average score of reflective writing from Week 1 to week 4

From discussion in Week 1, the participants' shared that they were afraid of making the wrong interpretation. Thus, they relied mostly from the textbook because they were afraid of exploring other perspective. Here lies the reason of the low score of information gathering section shown in Chart 5 above. Therefore, it is important for the writer to continuously remind the participants that it is okay to have different ideas with their peers' perspective.

Furthermore, it can be seen from the chart above that by the fourth week, the participants' score of information gathering reached its peak. In other word, the participants were more motivated to read and quote any related information to support their main ideas. The participants aware that they should not be afraid of having different point view as long as have strong supporting ideas.

Secondly, from Chart 5 above, it can be seen that there were only slight difference between the score in Week 2 and Week 3. Interestingly, the result of the reflective writing of a poem shows similar result with the response of a short story. Thus, it can be said that that even though some participants think that understanding poem is considered harder compared to short stories; but the participants were able to grasp the underlying meaning as long as they can relate with the issue from the poem. So, teacher must swift from the idea that poem is absolutely more difficult compared to short story. The participants shared that either short story or poem has its own challenge. Poem has fewer words but has its own underlying meaning. While, short story might be easier to read but sometimes also can be lengthy for the participants. Thus, both poem and short story can be a fun and meaningful a readerresponse activity when the participants can relate with the issue from the literary work.

\section{CONCLUSION}

From this research, it can be drawn that reader-response theory is beneficial to the improvement of participants' inadequacies in studying symbolism in literature. The idea of reader-response theory offers potential benefits to solve problems in literature discussion such as low self-confidence and fear of stating out different interpretations. From the discussion above, it can be seen by the fourth week 
the participants are more accustomed to express various ideas and share how the literary work affects their feelings. However, during the application of reader-response theory, it is important for the writer to remind the participants continuously that it is okay to have different perspective with their peers. Also, during the discussion session, the writer must always remember to avoid leading the participants into one solid answers. Consequently, the participants will be less afraid and be more engaged in the class activity.

The study suggest that reader response theory is applicable for teaching symbolism in literature. However, reader-response-based instruction has been criticized for the measurability of the readers' unlimited subjective responses. The present study shows the participants' progress by using Baron's rubric of critical thinking assessment. Thus, the present study recommend that further actionresearch-based studies deal with the same topic to explore and investigate the quality of participants' responses with other assessment techniques.

\section{REFERENCES}

Barron, C. N. (2015). Developing an assessment program to measure critical thinking: A case study at a small, online college. In S. Wisdom, \& L. Leavitt (Eds.), Handbook of reserach on advancing critical thinking in higher education (pp. 121-). Pennsylvania: IGI Global.

Basthomi, Y. (2001). Prose fiction in class: A retrospective. BAHASA DAN SENI, 29 (Edisi Khusus), 396-406.

Basthomi, Y. (2003). Theoretical views underlying the selection of classroom activities: Paying attention to the classroom of english literature in EFL context. TEFLIN Journal, XIV (2), 279-291.

Beach, R., \& Marshall, J. D. (1991). Teaching literature in the secondary school. Belmont: Wadsworth Publishing.

Bressler, C. E. (1994). Literary criticism: An introduction to theory and practice. New Jersey: Prentice-Hall International.

Bruns, C. V. (2011). Why literature: The value of literary reading and what it means for teaching. New York: The Continum International Publishing Group.

Day, R. R., \& Bamford, J. (1998). Extensive reading in the second language classroom. Cambridge: Cambridge University Press.

Devine, J. (1984). ESL readers' internalized models of the reading process. In J. Devine, J. Handscombe, R. A. Orem, \& B. P. Taylor (Eds.), TESOL '83. The question of control (pp. 95108). Washington DC: TESOL.

Febriani, R. B. (2019). The students' reflective writing manifestation of reader-response literary analysis. EDULITE Journal of English Education, Literature and Culture , 4 (1), 35-44.

Gale. (2016). A study guide for Franz Kafka's "Hunger Artist". Michigan: GALE-Cengage Learning.

Given, L. M. (2008). Introduction. In L. M. Given (Ed.), The Sage Encyclopedia of Qualitative Research Methods (pp. xxix-xxxii). California: SAGE Pulications, Inc.

Hargreaves, R. A., \& Robins, P. (1981). A prose course for advance level english in east africa. Nairobi: East African Educational Publishers Ltd.

Hatton, N., \& Smith, D. (1995). Reflection in teacher education: Towards definition and implementation. Teaching and Teacher Education, 11 (1), 33-49.

Herlina, N. (2016). Teaching literature through poetry: A shifting reading orientation from efferent to aesthetic. EDULITE Journal of English Education, Literature, and Culture , 1 (2), 225-238.

Iskhak, Saleh, M., Sofwan, A., \& Hartono, R. (2017). Investigating the effect of reader response journals on the quality of teacher trainees' responses to literary works. Theory and Practice in Language Studies , 7 (10), 831-840.

Langer, J. A. (1994). A response-based approach to reading literature. Language Arts , 71 (3), 203-211.

Lau, J. Y. (2011). Critical thinking and creativity: Think more, Think Better. New Jersey: John Wiley \& Sons. Inc.

Mays, K. J. (2017). The norton introduction to literature. New York: W. W. Norton \& Company, Inc. 
Kinasih, P., R.

McMahan, E., Funk, R., Day, S. X., \& Coleman, L. (2017). Literature and the writing process (Eleventh ed.). New York: Pearson education, Inc.

Moon, J. A. (2006). Learning Journals: A handbook for reflective practice and professional development. Oxon: Routledge.

New York Board of Education. (1931). Syllabus of minima in modern foreign language. New York: Board of Education of New York.

Orr, D. (2015). The road not taken: Finding America in the poem everyone loves and almost everyone gets wrong. New York: Penguin Press.

Robb, L. (2014). Vocabulary is comprehension: Getting to the root of text complexity. California: Corwin Literacy-SAGE Publicatios Ltd.

Robson, M. (2020). Introduction. In M. Robson (Ed.), What is literature: a critical anthology (pp. 1-7). New Jersey: John Wiley \& Sons Ltd.

Rosenblatt, L. M. (1988). Writing and reading: The transactional theory. Cambridge: Bolt Beranek and Newman Inc.

Shen, F.-Y. (2001). Coordinating Aesthetic stance and Efferent reading in Poetry. College English: Issue and Trends, 3.

Spiegel, D. L. (1998). Reader response approaches and the growth of readers. Language Arts, 76 (1), 41-48.

Trisnawati, R. K. (2009). Implementing reader-response theory: An alternative way of teaching literature reserach report on the reading of Booker T. Washington's Up from Slavery. Journal of Englisfmnd Education , 3 (1), 1-14. 